\title{
Where is God when dementia sneaks into our house? Practical theology and the partners of dementia patients
}

\begin{tabular}{|c|c|}
\hline \multicolumn{2}{|c|}{$\begin{array}{l}\text { Author: } \\
\text { Maria Bons-Storm }{ }^{1,2}\end{array}$} \\
\hline \multicolumn{2}{|c|}{$\begin{array}{l}\text { Affiliations: } \\
{ }^{1} \text { Women Studies and Pastoral } \\
\text { Theology and Counselling, } \\
\text { University of Groningen, } \\
\text { The Netherlands }\end{array}$} \\
\hline \multicolumn{2}{|c|}{$\begin{array}{l}{ }^{2} \text { Department of Practical } \\
\text { Theology, University of } \\
\text { Pretoria, South Africa }\end{array}$} \\
\hline \multicolumn{2}{|c|}{$\begin{array}{l}\text { Project Leader: Y. Dreyer } \\
\text { Project Number: } 2546930\end{array}$} \\
\hline \multicolumn{2}{|c|}{$\begin{array}{l}\text { Description: } \\
\text { Prof. Dr Maria Bons-Storm } \\
\text { is a research associate in the } \\
\text { project 'Gender Studies and } \\
\text { Practical Theology Theory } \\
\text { Formation', directed by } \\
\text { Prof. Dr Yolanda Dreyer, } \\
\text { Department of Practical } \\
\text { Theology, Faculty of Theology, } \\
\text { University of Pretoria. }\end{array}$} \\
\hline \multicolumn{2}{|c|}{$\begin{array}{l}\text { Corresponding author: } \\
\text { Maria Bons-Storm, } \\
\text { bonstorm@hetnet.nl }\end{array}$} \\
\hline \multicolumn{2}{|c|}{$\begin{array}{l}\text { Dates: } \\
\text { Received: } 26 \text { Oct. } 2015 \\
\text { Accepted: } 30 \text { Dec. } 2015 \\
\text { Published: } 31 \text { May } 2016\end{array}$} \\
\hline \multicolumn{2}{|c|}{$\begin{array}{l}\text { How to cite this article: } \\
\text { Bons-Storm, M., 2016, } \\
\text { Where is God when } \\
\text { dementia sneaks into our } \\
\text { house? Practical theology } \\
\text { and the partners of dementia } \\
\text { patients', HTS Teologiese } \\
\text { Studies/Theological Studies } \\
72(4), \text { a3227. http://dx.doi. } \\
\text { org/10.4102/hts.v72i4.3227 }\end{array}$} \\
\hline \multicolumn{2}{|c|}{$\begin{array}{l}\text { Copyright: } \\
\text { (C) 2016. The Authors. } \\
\text { Licensee: AOSIS. This work } \\
\text { is licensed under the } \\
\text { Creative Commons } \\
\text { Attribution License. }\end{array}$} \\
\hline Read online: & \\
\hline 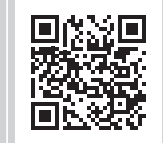 & $\begin{array}{l}\text { Scan this QR } \\
\text { code with your } \\
\text { smart phone or } \\
\text { mobile device } \\
\text { to read online. }\end{array}$ \\
\hline
\end{tabular}

How can hope, love and faith stay alive when dementia enters a home? In this article I shall look especially at the spouse or partner who shares an abode with a person with dementia. Most of the authors in this field, also John Swinton who is perhaps the best known author whose books are written from a (practical) theological perspective, focus on care in institutions, that means care by professionals. A partner living with a dementia patient has two main roles: as partner and caregiver. Night and day a partner is witness to the ongoing deterioration of her or his beloved partner, without being a professional. This article is founded not only on literature about dementia patients, but also on the experiences of several partners, as well as my own experiences as a partner. The question we all ask is: 'From where does our strength come?' I argue that what is said in the literature on the subject of (the pastoral care for) dementia patients does not help the partners, because it lays a heavy burden on them, who are already suffering from feelings of grief and guilt. I do not agree with John Swinton's idea that God created dementia. Looking for different ways of thinking about God and faith to survive with hope and love, I turn to the exegesis of the creation stories by Ellen van Wolde. These give the opportunity to take the evil of the situation of the deterioration of the personality of a patient with dementia seriously, and at the same time grant the possibility to turn the grief and guilt feelings into strength to fight evil, together with a God whose empathy and love stays with a partner in her or his loneliness and grief.

\section{Introduction}

God, grant me the serenity to accept the things I cannot change, the courage to change the things I can, and the wisdom to know the difference. (Original author unknown, see Shapiro 2008)

How can hope, love and faith stay alive when dementia enters a home? How do we meet God in a house of dementia? In this article I shall look especially at the spouse or partner (I shall refer to such a person as 'the partner'), who shares a house with a person with dementia (I shall refer to her or him as A).

My way of doing practical theology is to bring the experiences of people in their particular situation into a critical conversation with the Christian tradition, in order to look for ways people can live their lives with faith, hope and love, surviving the many dark spots on their route through life. I learnt this way of doing theology by being a feminist theologian, aware of the formative role of one's experiences, as a specific person in a specific context in the world. I was strengthened in this theological method by what I found doing my research on the development of faith in elderly women (Bons-Storm 2002). I found that these women made their own 'survival' theology during their long life with all its ups and downs. Although they often hid this process, they 'processed' what they learnt of 'dominant theology', the theology implicit and explicit in the confession of faith in their church, into their own way of thinking about God and the world, God in their own situation. In these postmodern times these survival theologies could be a starting point for new ways of thinking about God and the world, new steps on the long winding road of tradition - if they are heard. So my question is not: 'What has dominant theology, expressed in the "canonized" confessions of faith of the mainline churches to offer as inspiration and comfort to partners of dementia patients, but 'What are the needs and hopes of these partners and how could we think about God in a way that gives these partners faith, hope and love?'

In my research about faith and elderly women I found that dementia is the most feared disease among them. 'Cancer' brings the fear of dying, 'dementia' brings the fear of living with the loss of identity, loss of control, loss of self. 
There is a great amount of literature about (the person with) dementia from a medical and a psychological point of view. John Swinton is perhaps the best known author whose books are written from a (practical) theological perspective. Most of the authors in this field focus on care in institutions, that means, care by professionals. A professional has one role: caring for A for some hours, but after work going home. A partner living with $\mathrm{A}$ has two main roles: partner and caregiver. The partner lives in a home and a relationship suffering from dementia. Such a house has no possibility for escape and only a few, or no windows. Night and day a partner is witness to the ongoing deterioration of her or his beloved A. The partner is not a professional, although she or he reads many books on the care of dementia patients.

When two years ago my husband was diagnosed as having Alzheimer's disease, it was no surprise for me. Five years before this actual diagnosis it struck me for the first time that he forgot little things, which made him insecure. His memory had always been good; from then on it became worse. Dementia sneaks into a home as a thief in the night, deeply affecting everybody living in the house (Prins 1997; cf. Timmermann 2011:17). ${ }^{1}$ In the beginning there is confusion. I was deeply disturbed. My intelligent husband, with his leadership qualities, a fine theologian and pastor, became different: a very insecure person, totally dependent on me. My world changed, because the most important relationship for me changed. There is no hope things will become better. How could I respond to a situation that all the time changes for the worse? I talked about this with several other partners of dementia patients. This article is founded not only on literature about dementia patients, but also on the experiences of those other partners, and my own experiences. It struck me how similar the experiences of partners of dementia patients are. We, the partners, recognised our own experiences, grief, anger, feelings of guilt in each other's lives. The question we all asked is: 'From where does our strength come?'2 (To illustrate what I mean I use my own experiences, if not stated otherwise).

Many books about A give valuable insights. Not the same amount of attention is given to the partner. In this article I shall try to bring to the surface what ideas about God and the world are implicated for a partner.

\section{The situation and experiences of the partner}

A and her or his partner are usually older than middle age, so they are not on top of their strength and energy. In many cases the children - if the couple has any - don't live near their parents, like in olden times, but somewhere else, even abroad. The partner has known A when she or he was still healthy and loved A. The partner is at the same time the most important person to $\mathrm{A}$ in an emotional way and the

1.Sophie Prins (1997) describes Alzheimer as a thief in the night, coming into the house silently, stealing what is most precious in the partner's life: her or his husband.

2.Adrienne Rich (1983), from the fourth poem: 'With whom do you believe your lot is cast. From where does your strength come?' main caretaker. As such, a partner is witness to the ongoing deterioration of the personality of $\mathrm{A}$, which is deeply painful.

The first phase of dementia is experienced by the partner with unbelief, fear, being disturbed. Why does A behave like this, so differently from how she or he usually behaved?

\footnotetext{
'My husband always knew his way around, never got lost. Then, five years ago, suddenly insecure, he asked me at a crossroad on a road we drove on often: 'Left or right here?' I was confused: Does he not concentrate, thinking of other things? This behaviour is very strange'.
}

This is a time of tension in the relationship, of reproach, of blame, of irritation, anger and fear. In many cases the partner feels guilty after being irritated or angry.

When the dementia advances, partners are afraid to die or to become ill, to be hospitalised. A cannot survive alone. A cannot structure time. When A awakes in the morning, he does not know what time, what day it is. Time stretches before her or him as an ocean without limits, but also as a void. The partner has to function as the remote control over A's actions:

'My husband was a great reader and he still reads - but now frequently he reads the same chapter - about his favourite topics. He wanders a lot through house or garden, or sits, doing nothing. So sometimes I say: 'Won't you do anything or read something?' just to end seeing him staring out the window. This behaviour is painful to see: It is so very different from my husband's behaviour in his healthy days: active, full of interests, too busy sometimes'.

The partner usually does everything to get A as well as possible through the days, but worries. 'What if I am not there?' Not only time is unstructured, so is space:

'When nowadays my husband and I walk together, as we used to do, I realise that even on walks we used to do nearly weekly, my husband follows me into the great unknown. Long walks become difficult for him because he is hampered by insecurity. So the walks together with him become shorter, although I, the partner, love to go greater distances. But I have to adjust myself to his pace. Often the only safe, secure place is home and the nearest neighbourhood. The world outside is a vast place of insecurities'.

'When my husband is taken on a trip to visit relatives or friends, he asks again and again: "Where am I, where are we going, what are we doing here?"'

The reality and feeling of loss is a poignant quality of the partner's experience. A is there but also not there. He looks the same as always, although his insecurity is visible in the way he moves. Sometimes, in the first and middle stages of dementia, other people do not notice that A is ill. Often, the 'automatic social pilot' still works in short encounters. But the relationship between the partner and A changes until there is no real communication possible between them. What is said by the partner evaporates in a few minutes or seconds in the mind of $\mathrm{A}$, who lacks a frame of reference to give meaning to what is said and also lacks the possibility to store it in his or her memory. This is a great source of unhappiness, mostly for a partner, for A 'forgets that she or he forgets'. 
The partner experiences a situation of fake widow(er)hood (Kevern 2010:174). ${ }^{3}$

\section{It is my experience that:}

'Every day I see my husband change into somebody else, not my husband, different, often not nice, not lovable, irritating in his lack of understanding simple questions, simple situations. Endlessly repeating the same remarks. Forgetting everything I say. Communication becomes shallow and nearly impossible. Why talk to him? It goes straight through his mind, he forgets it right away. I am not patient enough. I do not love him enough. Where has he gone? I lost him, but I am not yet a widow, in an 'official' bereavement. But I am in mourning, although people do not realise it. Is mourning a sign that I still love him enough?'

A is there, her or his body can be touched, but not as the person who she or he was, that was more than 'a body'. The body is important, the more in a relationship with strong erotic and sexual aspects. A is no longer a sexual partner, intimacy goes away. A friend told me:

My husband still made love to me during the first stages of dementia. Till he began to think that I was his favourite sister. Then he asked: 'Can we still make love?'

\section{A very difficult time comes when a doctor says:}

'It is best if your husband went into day care. At home he does not get enough incentives to stay busy and it will also be good for you, it takes the load of caring for him off your shoulders, for one or more days a week.

I felt relieved and at the same time very sad. Fortunately my husband liked to be in the very friendly day care centre. But I felt sad, because we are not together in one house anymore. I cannot care enough for him. I have to bring him to someplace else and leave him there. And I feel very guilty because my first reaction was feeling relieved'.

But the situation can be worse. A friend, whose husband is a dementia patient, told me:

'I wanted for my husband to go into day care, and later into a geriatric hospital. It was too difficult to take care of him at home. He vented his anger and frustration towards me. He threw cups of coffee at me, sometimes hit me. And he used to be a very nice, loving man. My daughters were also convinced that he could not any longer stay at home. But my son, living not in our neighbourhood, was against it. "You cannot put father away. It must be possible that you care for him", he said. It was very difficult. I think my son was afraid he too would be 'put away', as he called it, when he would be old'.

All the partners I spoke with and I, have feelings of guilt about the continuously changing relationship with A. Partners do not know how to react when their wives or husbands behave in strange ways, when they repeat some remarks or stories many, many times, when they are clumsy, unable to do simple things. Not every partner has a lot of patience getting used to each new stage of the illness. Partners are nearly constantly frustrated, but they have no address for their frustrations. They become angry, but at A? No, they know

3.'Those who are close to the person with dementia tend to speak more of a sort of bereavement' (Kevern 2010:174).
A is ill. Every impatient remark towards A causes guilt feelings. Often the anger becomes directed at themselves, they hate themselves because they are angry at an ill person, who is not responsible for her or his behaviour. How can the partner avoid to have negative feelings about A when, because of A's illness, the partner's life has changed so much for the worse? When the partner's freedom is limited to care for A? Being a partner of a person with dementia is living with many ambivalences:

- I am angry at A - of course I am not angry, she or he is ill.

- I love my partner who is demented - I don't love this person any more, she or he is not the person I married.

- I wish A would die before the dementia gets worse and destroys the whole personality of the person I love so much - I am bad, wishing A dead.

- I want to do what I want: Go out, do my own things, not be hampered by A - I must in the first place care for A, be there for her or him. That is what God asks from me, that is real love. But isn't God asking too much?

Feelings of loss and guilt, but also of loneliness, longing, insecurity and exhaustion colour the days of the partners. Sometimes they envy partners of cancer patients although they know that those partners also suffer a great deal. But those partners can still communicate with their loved ones, which is impossible for partners of A. A does not know her or himself anymore, but often the partner also feels she or he becomes someone else: In the first place a person unable to cope with a relationship all the time is changing for the worse.

\section{The partner's situation acknowledged}

Although most books are mainly about A, there are some books that give special attention to the partner. For instance, the Dutch journalist Jessie van Loon (2006) wrote a very helpful book focusing on partners, explaining what happens in the brain and behaviour of A and giving practical advice.

Carla Schölzel-Dorenbos (2011), a Dutch geriatrician, combines several well-documented research studies about the quality of life of dementia patients and of their informal caregivers, in my words 'partners'. She mentions as the outcome of research about the needs of caregivers:

Care giving can result in social isolation, psychological stress and depression. Caregivers of Alzheimer's disease patients living at home most often need physiotherapy for the patient, financial support, house cleaning and respite home care during holidays. (Schölzel-Dorenbos 2011:70-71)

Another outcome of the research studies mentioned in Schölzel-Dorenbos's book is: 'Caregivers, mostly the partners, experienced a lower quality of life than Alzheimer's disease patients and healthy Dutch elderly' (Schölzel-Dorenbos 2011:93, 100). These research studies show that the domains of marriage and family strongly affect the quality of life of caregivers and/or partners. 'Possibly negative effects of the 
partner's [i.e. here: the dementia patient,] condition can be compensated by well-functioning family ties and adaptations in marital relationships' (Schölzel-Dorenbos 2011:107).

These last words can place a burden on the shoulders of partners.

\section{Reflections on the experiences of partners from a psychological viewpoint}

Tom Kitwood was an English psychologist and an ordained priest, who greatly influenced the view on dementia and the care for demented people. Contrary to the opinion that dementia is a result, in a linear way, of a neurological disorder, he argues that dementia is in the first place a relational and social disorder. The more a person lives a life with benevolent emotional experiences, with acceptance of her or his person in her or his environment, the less a neurological disorder also to Kitwood the sine qua non basis for dementia - will cause symptoms of dementia. He even states: '[G]iven an appropriate social, relational, and spiritual environment, a degree of rementing can take place' (Kitwood 1997:19).

The North American neuropsychologist Steven Sabat takes Kitwood's thinking further. He names 'malignant social positioning' as a major factor in the development of dementia (Sabat 2008:81). One cannot say that a person suffering from dementia loses her or his self for this self is being maintained by appropriate social encounters (Sabat 2001:277).

The theories of Kitwood and Sabat make the partner, the person most near to A, often having related to her or him most intimately for years, responsible for the development of dementia. The suggestion of the possibility of 'rementing' by appropriate love and care for A puts a heavy burden on the partner. I do not agree with Kitwood and Sabat, because they deny the decisively great impact of neurological disorder of the brain on the personality of a person.

In an earlier publication (Bons-Storm 1989:23-45) I argued that all human beings are on a journey through life composing their identity, in this case understood as their narrative of who they are, on the basis of their interpretations of the past - that is: their memories - and of their anticipations of the future. Referring to this I wrote later that as such our identity can be understood 'as a developing story from our point of view in our particular context on our journey through life' (Bons-Storm 2015:43). Romin Tafarodi (2015:25) writes: 'The very structure of human experience rests upon our threefold subjective awareness of past, present, and future.' These arguments show the importance of memory. See also Jessie van Loon (2006:15) who writes: 'Not a second goes by without our using our memory.' When dementia develops, increasing loss of memory makes it difficult, even impossible to interpret each 'now'. The result is insecurity, not only about what happened in the past, even the most recent past, but also about all experiences in the 'now', which cannot be interpreted.
Where am I now, who is the person I meet, why am I here, where am I going, and ultimately: who am I?:

'Once, when my husband found me crying in the bedroom because I was sad because he had changed so very much, he asked: "Why are you crying?" I answered honestly: "Because you are not any longer who you were". He said: "Well, I absolutely don't know who I was or who I am now"'.

In this debilitating insecurity, which I see as one of the basic characteristics of dementia patients, A often falls back on basic tactics to fight insecurity, to fight any unpleasant feelings. Depending on the basic character traits of A these tactics will be somewhere between the poles aggression - to withdrawal.

If a partner sees this overwhelming insecurity, she or he often does not know how to deal with A. She or he wishes to do everything possible to lessen it. But it is very difficult to have real empathy with a person who is unable to interpret what is happening, without having memories. The partner experiences the lack of real communication and is frustrated and often angry. This again gives the partner the burden of guilt. How does a partner deal with God's will to love A unconditionally, with a love that heals $\mathrm{A}$ ?

\section{Thinking from a theological point of view}

The British theologian Peter Kevern wrote a summary of the opinions of theologians, who wrote about dementia (Kevern 2010:174-182). He distinguishes three approaches to the subject:

- thinking theologically as a pastor, looking for words of assurance, for instance, the person with dementia is remembered by God, whether a person remembers God and keeps her or his faith, or not

- theological thinking focussing on the 'eclipse' of the identity of $\mathrm{A}$ and the belief that the identity of $\mathrm{A}$ is held in the community, for instance the community of the church (p.174)

- 'recognising the person with dementia as imago dei' (italics by Kevern 2010:174).

\section{John Swinton}

Probably the best known theological author on dementia is the British practical theologian John Swinton. I refer here mainly to his book Dementia: Living in the memories of God (2012). Swinton looks for a theological foundation to offer a pastoral, reassuring message to the patient of dementia and her or his caregiver. According to Swinton practical theology provides a counter story and in this counter story A is not a person with a deficit, a patient, somebody with a diagnosis, typecasting her or him as a member of a specified group of persons (Swinton 2012:54). In Swinton's view A is in the first place a full and unique person, God's creature who has a special meaning, as every human being has. Following Kitwood and Sabat, Swinton (2012:77-78) states that there is no linear 
relationship between the development of neurological damage and that of the symptoms of dementia, for a person's brain is shaped by her or his experiences:

Rather, the assertion is that relationships may be both causative and formative within the development of the syndrome of experiences and neurological damage that forms dementia. In other words: relationships are part of what dementia actually is, not just aspects of how we should offer care for people once the condition has been defined. (italics by Swinton 2012:71)

This means that: 'No longer can we avoid responsibility for dementia by blaming it all on neurology' (Swinton 2012:80). Swinton (2012:234) sees as good care for people with dementia 'an ethic of intimacy and love [...]. Strictly as a way of being, not with any expectation of cure or any other instrumental goal.' A good caregiver has to work with 'lived time', not with 'clock time'. Lived time is time, redeemed by God, making that we live in an eschatological space, providential time (p. 235). We have to learn being with $\mathrm{A}$ in the present, sometimes without words.

The caregiver Swinton speaks of, works in an institution, but it can be assumed that the same is asked from a caregiver at home. Being with somebody, acknowledging the other as a particular, unique person is certainly a strong medium to try to call the hidden or lost self of A to the surface. However, my objection to this statement by Swinton is: the present in which A lives is not identical to the present in which caregivers live. For a 'healthy' caregiver each present is related to other presents in the past, in a chain of memories that gives the opportunity to giving meaning in a particular 'now'. A lives in an isolated 'now', most often unable to give meaning to this 'now', this present. Moreover, A's partner is not a professional caretaker. The partner has lots of other things to do: perhaps she or he still has a job, perhaps she or he works somewhere as a volunteer, and enjoys it; there is the shopping to do, the cooking, cleaning, receiving visitors. 'Clock time' is necessary for many of these tasks. Although the partner longs for time for her or himself, Swinton underlines what she or he must do: The partner must, in the first place, be there for $A$. That is what God asks from a partner, real love.

\section{The remarks by Swinton give partners a lot of guilt feelings}

It helps partners to see A's behaviour as symptoms of an illness, that befell A not caused by his or our shortcomings. It remains the responsibility of partners to react to A's symptoms as lovingly as possible, but they all said they cannot always 'be there'.

Swinton's (2012:184) theological point of departure is creation, 'nothing exists apart from God's desire for it to exist. Strangely, this includes dementia.' Swinton's core message is: A lives in the memory of God. God remembers us 'as we actually are, not simply as we think we are or have been' (p. 213, italics by author). He rejects the opinion of Kevern that the remembering God stays distant from the experiences of A so that there is only the eschatological hope that God will make everything right in the end (Kevern 2010:175). Indeed, Swinton's idea of God is at the same time of a God who is with human beings always, and a God who looks at human beings from the outside. For Swinton A is not only held in the memory of God, as she or he 'actually is' but also in the community, the church, people who also try to see her or him as she or he 'actually is'.

My questions after reading Swinton's opinion have to do with two points: did God really create dementia, making the loved one, A, as he or she is now, often making others unhappy, feeling guilty? This question implies that I have to think about the origin of evil. The other question is: What is this 'actual self'?

\section{An 'actual self' remembered by God?}

I agree with Swinton's (2012; italics by Swinton) opinion:

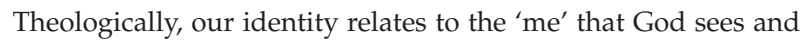
remembers. This has a direct bearing not only on persons' endurance after death and their identity when they have dementia, but on every moment they exist [...].To be remembered by God is to endure in the present and into eternity. (p. 218)

What or who is the 'me' that God sees? 'Me' is the object form of ' $\mathrm{I}$ '. It is the way one sees oneself. In the quote of a dementia patient I gave before, he says: 'I absolutely don't know who I was and who I am now.' His 'me' is fuzzy. Speaking for myself: my husband's personality had many stages; he was the endearing toddler I know from pictures; he was the intelligent, charming adolescent I fell in love with, he was the competent adult, loving spouse, dear father of his children, busy minister and pastor, ever developing theologian and now he is the helpless man, without memory or ideas, totally dependent on me. He is a developing human being. A very important characteristic of human beings is that they change, they grow, blossom and decline. I believe that for God each stage in the development of life, each with its own capacities and limitations, is safe in God's heart.

What or who exactly continues to live in the memory of God? I have learned that it works best for me when I concentrate on trying to communicate with and care for $A$ as he is now, not all the time consciously or unconsciously comparing A's demented personality and attitudes to his former, 'healthy' personalities. This point comes back later in this article, thinking of A as also a human being in God's image.

\section{Did God create dementia, as Swinton writes?}

When we think about God, we must keep firmly in mind we do not deal with facts, but with beliefs, opinions, imagery and stories, told from a certain point of view, with a certain intention, in a certain culture in a certain historical setting. Some manners of thinking about God and the relationship between God and the world tend to survive the change of contexts. In this manner dominant theologies are born, often assuming to know the truth about God and the world. The opinions of Swinton reflect the problem, inherent in dominant Christian monotheism: how can the One Almighty God who 
is supposed to be the Creator of all that is, loving and merciful, at the same time allow, or even create, so much suffering? (Siertsema 2011:124). But there are strands of tradition next to the dominant ones, and many people nowadays choose their own way of 'processing' the traditional imagery and ideas about God and the world, taking their own longing and specific needs for faith, hope and love seriously. They are helped by theologians who have the courage to think afresh about God and the world, taking the traditional imagery and stories in the context of the times and culture, in which they originated. The partners of dementia patients I spoke with and I myself are disturbed by theologies that point to God himself as the giver of dementia, either as a punishment or as a pedagogic measure, or as a mystery.

Swinton (2012:184) states explicitly that God created everything, so God created dementia also: 'It is not the work of the devil. It is a mystery which is firmly rooted in God's creative and redemptive actions in and for the world.' This is not an inspiring and comforting message to partners of dementia patients. How can I imagine this, using the imagery of the creation story of Genesis? Was dementia God willed, was it part of the good creation? Partners of dementia patients cannot do otherwise than be convinced that dementia is evil. It causes destruction, not only in the minds and personalities of dementia patients, but also in their families. Dementia is evil, in a concrete sense, in its particularity of causing suffering in concrete persons. Before we think about God as creator of dementia - and the rest is mystery - we have to take this suffering seriously.

Thinking about the old questions concerning the goodness of God and the reality of evil, the point of departure of the Dutch theologian Erik Borgman (2011:27) is: 'God is good and God has the last word.' Referring to John 1, verse 15 he states that there is no realm of darkness and we need not protect the light against the darkness. Nevertheless the suffering has to be taken seriously: life seems meaningless to many persons, despairing in its absurdity, heading towards death. Borgman refers to the atheist French philosopher and novelist Albert Camus, who has no illusions about life: it is without meaning and often absurd. He states that the only answer to this absurdity is love. Not love as a concept, but the concrete solidarity with specific persons in their specific situation (see Camus 1956). Borgman goes further and refers to the theologian Edward Schillebeeckx and his concept of 'contrast experience': the experience, common to all people that:

$[I] \mathrm{n}$ life in the world as she is sometimes the evidence erupts that things are not as they should be. [...] In this intuitive human experience of what is good, implicitly present in resistance to evil that, seen from a human viewpoint, surfaces spontaneously, Christians see, according to him [i.e. Schillebeeckx], a sign of God's compassion with creation and humanity. (Borgman 2011:40; transl. from the Dutch by author)

According to Schillebeeckx, resistance to evil has meaning and the victory of the good life has begun and Jesus, the firstborn of a new creation, brought this to light (Borgman 2011).
These opinions can bring some hope to partners, as they acknowledge to the full the absurdity and meaninglessness of human suffering that evil creates, and stress the good of ongoing solidarity as resistance, of never only resigning in the trust of God's mysteriousness. On the other hand, how can we experience, in the hopeless situation of dementia that the victory of the new creation has already begun?

Before jumping to a new creation, let us concentrate again on the creation stories of Genesis, the 'first creation'. Did God create Alzheimer's disease, as Swinton states explicitly? Thinking about creation and evil, Ellen van Wolde, a Dutch scholar of the Old Testament, researched the text of Genesis 1 and translated the Hebrew 'bara' not with 'to create', but with 'to separate'. The Hebrew verb 'asa' she translates as 'to make'. This was not new, but still the way she translated Genesis 1 and drew her conclusions shocked many theologians. She translates Genesis 1 verses 1-4 as follows:

In the beginning, when God created heaven and earth, and the earth was without foundation and darkness was lying over the deep, and God's breath was hovering over the face of the waters, God said: 'Let light be'. There was light. God said: 'It is good'. God separated the light from the darkness. (Van Wolde 2009:31; translation from the Dutch by author)

God continues to separate, making order in the chaos that was. No creation ex nihilo. Van Wolde argues that the story of Genesis does not tell us about the beginning of the world, but about the start of God's acting in the world.

Hermann Häring takes this further in a theological way. He argues that God did not create evil, but that the chaos of the tohuwabohu still exists. God's acting in the world is also God's battling with this chaos, and humans are invited, as partners of God, to join in this work, keeping God's creation good, fighting against all suffering and destruction. If we think and speak about 'evil' as a concept, we run the risk of not distinguishing the perpetrators from the victims. 'Evil' in all its forms has to begin with the articulation of suffering in its many different kinds (Häring 2011:14). God is at the side of the victims of chaos, which is commonly accepted as the translation of tohowabohu. The same is argued by the French theologian Lytta Bassett (2001:8): evil is what hurts. We have to think and speak about evil starting from the experience of 'evil'.

We can think of tohuwabohu, 'the dark' and 'the deep' as chaos, as the ongoing power to cause chaos: muddling, disturbing, destroying, causing suffering. We feel this in our body, our mind and psyche: we suffer pain and illness in various ways, including dementia. The power of chaos also allures humans to make bad choices, that is, to destroy immediately or in time - right and just relationships and causing domination, usurpation, colonisation, war, suffering to many. Thinking in this way God did not create evil, including dementia, but is battling against dementia, and against all issues of the disturbing powers of chaos. This is part of God's ongoing 'creative' work, and we can be allies of God. Using the symbolic language of Genesis 1 we live in 
hope of the 7th day, the Sabbath. Then God's desire for a good ordering of the good world will be fulfilled.

How can this theological theory be translated into practices? Not by trying to rement (the word introduced by Kitwood 1997:19) A by the partner's superhuman effort to be 'always there', meeting A in 'redeemed time', but by knowing one's boundaries. A wise person prayed once: 'God, grant me the serenity to accept the things I cannot change, the courage to change the things I can, and the wisdom to know the difference' (it is not clear who the author of the so-called 'serenity prayer' is, see Shapiro 2008). When we battle with God against dementia we try to make A's life as comfortable and happy as we can, we look after ourselves in order to stay fit to care for A. We give our contribution in money or other things to scientific research for the causes and possible cures of dementia. God works in God's own way towards the good life, the ending of suffering. The power of chaos is strong. According to the imagery of the Genesis story God did not make the world in one moment, waving a magic wand. For each step God needed a whole day and for the whole work six whole days, before God could say that it was good as it was. Faith is also trust that God is still creating this world, needing us to join him or her.

There are many stories possible about God and the start of the world. I agree with Häring that in our postmodern times container concepts like 'evil' do not work anymore in people's lives. It is better to take as our starting point the experience of so many forms of suffering in this world. The loss and guilt feelings of partners of dementia patients can be lessened if these partners try to believe and hope that God did neither create the suffering of their partners, nor their own suffering. Suffering is part of the bottomless chaos, still existing at the fringes - and sometimes at the centre - of this world, God's good creation. Partners can pray to God, asking for strength to fight the chaos, while God is their ally. They have to learn that their anger is not directed towards $\mathrm{A}$, but towards the illness. This anger can be transformed into positive feelings, courage and strength.

\section{Thinking about God and dementia with 'imago Dei' as a starting point}

Genesis 1, verses 26-27 tells the story that God (v. 26) made (form of the verb asa, to make) Adam, that is the human being 'in our image, after our likeness' and verse 27: God created (form of the verb bara, meaning to separate or to create) the human being in his image, separated it in the image of God, male and female he separated them. These texts lead the imagery about the unimaginable God, culminating in the theological idea and the imagery of the Divine incarnation in Jesus of Nazareth. In this emphasis on the 'alikeness' of God and human beings of both sexes being created in the alikeness, the message is heard that God and human beings have things in common, are 'related' to each other. Much is speculated about which traits are common in God and humans. Here I say only that as God is thought to be a perfect being, it is often thought that only the most perfect human beings can have traits in common with God: male (in our late - but not post-patriarchal societies), pure, unblemished human beings. Jesus, according to dominant theologies 'the Son of God', can as such be understood as the human being who is like God as a son is like his father. One could say: if one saw Jesus of Nazareth, one could imagine how God could be. Genesis speaks of all humanity being created in God's image, but one could say that in the person, the lifestyle, the character and the ethics of Jesus, in his time and context, the likeness had a unique quality.

The North American theologian Nancy Eiesland takes in her book The disabled God (1994), Jesus (later acknowledged as the Messiah), as the prototype of a person 'in God's image'. Although the power and concreteness of incarnation is often made abstract in centuries of theological constructions, Eiesland (1994:99) states: 'Yet Christology is fundamentally about human experience and human bodies as partially constitutive of God.' She was a disabled person who died young and her point is that God is visible in ordinary, even disabled, flawed human beings. Jesus was told to be tired and Jesus' body was mangled on the cross, but still he was 'God's image':

The resurrected Jesus Christ in presenting impaired hands and feet and side to be touched by frightened friends alters the taboo of physical avoidance and calls for followers to recognize their connection and equality at the point of Christ's physical impairment. (Eiesland 1994:101)

Peter Kevern (2010:174) asks: 'What sort of God do we worship if the dementing person is in God's image?' He writes: '[T] the task is the old one of 'thinking together' God's vulnerability and God's power' (Kevern 2010:180). He understands the idea of the 'imago Dei' not as a similarity between God and humanity, but as a solidarity between Creator and created. 'We learn the truth of our experience by reflecting upon God; and we learn the truth of God by reflection upon our experience' (Kevern 2010:176). In many strands of theological tradition God is imaged not as a detached God, but as a God who feels connected to, concerned with, even related to human beings. The imagery of 'God the father' mirrors that idea. This means that the theological idea of seeing human beings as 'imago Dei' speaks about the possibility of empathy between God and every specific person, disabled, very tired or in other conditions. This means that both the person with a disability in her or his brain, demented; and the carer, tired, exhausted, can meet God in each other. I, as a partner, may believe, may trust, that God feels empathy with me. God understands my grief, my anger, my fatigue; God even understands that I feel guilty, and forgives. I, as a woman, am most comforted and inspired by this idea when I imagine God as a Mother. If I, a woman, am made in God's image, then God cannot be imagined only as a father. I am comforted and inspired by the empathy I feel between God the Mother, who feels the anger about the suffering of a beloved one, grieving about the pain of her beloved creatures. She gives me strength and loves me unconditionally 
according to the amazing idea of true grace. I am also inspired by the idea of Ellen van Wolde (2009) that God is also still battling the powers of evil at the fringes of creation. Bound to God by solidarity and empathy, partners of dementia patients may feel God at their side in the house of dementia, battling along with her from day to day, working at and hoping for the situation when God's desire for the end of pain, suffering and the many forms of injustice, caused by chaos, shall conquer.

\section{Acknowledgements Competing interests}

The author declares that she has no financial or personal relationships which may have inappropriately influenced her in writing this article.

\section{References}

Bassett, L., 2001, De macht om te vergeven. Kwaad loslaten en vrij worden, Altiora, Averbode.

Bons-Storm, R., 1989, Hoe gaat het met jou? Pastoraat als komen tot verstaan, Kok, Kampen.

Bons-Storm, R., 2002, Kracht en Kruis. Pastoraat met oudere vrouwen, Kok, Kampen.

Bons-Storm, R., 2015, 'Complex identities: Complex patterns of belonging', in P. Couture, R. Mager, P. McCaroll \& N. Wigg-Stevenson (eds.), Complex identities in a shifting world. Practical theological perspectives, pp. 43-52, LIT Verlag, Wien.

Borgman, E., 2011, 'Zijn is goed zijn. Theologisch eerherstel van het beeld van het kwaad als "privatio boni"', in B. Musschenga \& B. Siertsema (eds.), Het Kwaad: Reflecties op de zwarte zijde van het bestaan, pp. 26-46, Skandalon, Vught.
Camus, A., 1956, La Peste, Gallimard, Paris.

Eiesland, N.L., 1994, The disabled God: Toward a liberation theology of disability, Abingdon Press, Nashville.

Häring, H., 2011, 'Spreken over de afgronden van de wereld: Een essay over het kwaad als begrip in het denken', in B. Musschenga \& B. Siertsema (eds.), Het Kwaad: Reflecties op de zwarte zijde van ons bestaan, pp. 10-25, Skandalon, Vught.

Kevern, P., 2010, 'What sort of God is to be found in dementia? A survey of theological responses and an agenda for their development', Theology 113(873), 174-182.

Kitwood, T., 1997, Dementia reconsidered: The person comes first, Open University Press, Buckingham.

Prins, S., 1997, Dubbel verlies: Getroffen door de ziekte Alzheimer, Kosmos Z\&K, Utrecht.

Rich, A., 1983, Sources, The Heyeck Press, Woodside.

Sabat, S.R., 2001, The experience of Alzheimer disease: Life through a tangled veil, Blackwell, Oxford.

Sabat, S.R., 2008, 'Positioning and conflict involving a person with dementia: A case study', in F.M. Moghaddam, R. Harré \& N. Lee (eds.), Global conflict resolution through positioning analysis, pp. 75-82, Springer, New York.

Schölzel-Dorenbos, C., 2011, 'Quality of life in dementia. From concept to practice', Doctoral thesis, Medical Department, Radboud University, Nijmegen, the Netherlands.

Shapiro, F.R., 2008, 'Who wrote the Serenity Prayer?', Yale Alumni Magazine, July/ August, viewed 19 February 2016, from http://archives.yalealumnimagazine. com/issues/2008_07/serenity.htm

Siertsema, B., 2011, 'Het rechtsgeding tegen God volgens de Bijbel, Abel Herzberg, Elie Wiesel en Frank Cottrell Boyce', in B. Musschenga \& B. Siertsema (eds.), Het Kwaad: Reflecties op de zwarte zijde van het bestaan, pp. 124-140, Skandalon, Vught.

Swinton, J., 2012, Dementia. Living in the memories of God, Eerdmans, Grand Rapids.

Tafarodi, R., 2015, 'Narrative identity and the challenge of multiculturalism', in P. Couture, R. Mager, P. McCarroll \& N. Wigg-Stevenson (eds.), Complex identities in a shifting world: Practical theological perspectives, pp. 7-18, LIT Verlag, Wien.

Timmermann, M., 2011, Goede zorg voor mensen met dementia: Presentieverrijkte verpleeghuiszorg, Boom Lemma, Den Haag.

Van Loon, J., 2006, Mijn partner raakt de weg kwijt: Omgaan met dementie, Pearson Education Benelux, Amsterdam.

Van Wolde, E., 2009, Terug naar het begin, Valkhof Pers, Nijmegen. 